\title{
Transformational Leadership and Work Unit Innovation: A dyadic two-wave investigation
}

\begin{abstract}
Mobilising arguments from conservation of resources theory (COR) and employing time-lagged, multi-source data, we propose and test a model connecting unit level transformational leadership (TFL) to work unit innovation performance. We theorise that unit level TFL, comprising idealised influence and inspirational motivation, will impact unit innovation performance through a double mediation mechanism involving unit knowledge sharing climate and internal to unit knowledge sharing. Dyadic data from 124 unit leaders and 644 employees collected at two time points broadly support our predicted pathways. In generating insights into the mechanisms linking unit level TFL to work unit innovation performance we highlight the importance of ambient-level TFL behaviours in explaining innovation performance and we answer calls in the literature for research designs which can assist in unearthing indirect relationships in the TFL-innovation nexus.
\end{abstract}

Key Words: Conservation of Resources Theory; Work Units; Transformational Leadership; Knowledge Sharing Climate; Unit Knowledge Sharing; Innovation Performance. 


\section{INTRODUCTION}

Innovation is a critical organisational capability linked to sustained competitive advantage (Li, Mitchell, \& Boyle, 2016) and therefore, it is hardly surprising that both firms and management researchers have a sharp focus on how leaders contribute to innovation performance. Scholars have suggested that leadership is one of the most significant predictors of innovation (Jia, Chen, Mei \& Wu, 2018; Sanders \& Shipton, 2012) and that transformational leadership (TFL) in particular may serve as a conduit to securing innovation gains (GarcíaMorales, Jiménez-Barrionuevo \& Gutiérrez-Gutiérrez, 2012). Findings on the TFL-innovation link are not conclusive with researchers highlighting the need for cross-lagged designs, the requirement to investigate mediators, and the identification of TFL behaviours that are appropriate to understand innovation at the work unit level (Rosing, Frese \& Bausch, 2011; Pieterse, Van Knippenberg \& Van Ginkel2011). For example, Chen, Tang, Jin, Xie \& Li (2014) have argued that TFL behaviours such as individualised consideration and intellectual stimulation are more relevant to individual-level innovation behaviours because they emphasise dyadic relationships between the leader and her direct report. Dong, Bartol, Zhang \& Li (2017) proposed that both individualised consideration and intellectual stimulation are developmental in nature and emphasise individual coaching, and mentoring based on employee needs and abilities. They also help individual employees to think differently about challenges. In contrast Li et al. (2016) conceptualised idealised influence and inspirational motivation are ambient type TFL behaviours that in turn impact group behaviours. Dong et al. (2017) highlight the role of idealised influence and inspirational motivation in getting employees to collectively think about innovation within the team. Therefore, these ambient dimensions of TFL can infuse the work unit to prioritise collective innovation goals (Kark \& Shamir, 2002). Scholars have also suggested that different mediators may be relevant in explaining the link between the different dimensions of TFL and innovation (Hughes, Lee, Tian, Newman \& Legood, 2018.) We also 
observe that a significant amount of research has focused on upper echelon leadership (Zuraik \& Kelly, 2019; Chen et al 2019) whereas there is much less emphasis on leaders who are in the trenches and close to the operational realities of the work unit. For the purposes of this paper we conceptualise innovation as the collective intentional generation and implementation of new ideas specifically within the work unit (Janssen \& Van Yperen, 2004).

To frame our study on the relationship between TFL (idealised influence and inspirational motivation) and work unit innovation we utilise arguments from conservation of resources theory (COR) (Hobfoll, 2011; Halbesleben, Neveu, Paustian-Underdahl \& Westman, 2014) and specifically the resource investment principle and resource caravans' concept. COR theory emphasises a resource investment as well as resource loss. However studies have primarily focused on resource loss (Kossek \& Lautsch, 2018). A resource investment perspective is particularly important in the context of innovation because of the high failure rates in innovation implementation estimated to be between 60 and 90 per cent (Brown \& Anthony, 2011; Blank, 2013). COR theory proposes that it is the perception of available resources that is important rather than the actual amount of resources (Clarkson, Hirt, Jia \& Alexander, 2010) and it helps explain why unit members regulate their personal resources in response to resource gains from both TFL and unit knowledge sharing climate to achieve unit innovation We argue that where unit employees or followers have positive perceptions of TFL this will directly impact innovation as well as through other resources (Mao, Chiang, Chen, Wu \& Wang, 2019). Therefore, if a unit is facing a difficult or challenging innovation problem where it has a leader who demonstrates idealised influence and inspirational motivation, combined with a strong unit knowledge sharing climate, this will support unit knowledge sharing which leads to innovation.

We make three contributions to the TFL-innovation link. First, we investigate a double mediation model of the link between TFL and unit innovation focusing on unit knowledge- 
sharing climate and internal to unit knowledge sharing as mediators. This model is consistent with the COR concept of resource caravans which are defined as combinations of resources consisting of environmental conditions that support and enrich the resources of unit members to engage in knowledge sharing and generate unit innovation outcomes. We conceptualise both TFL and unit knowledge sharing climate as contextual resources. We define unit knowledge sharing climate as an emergent state (Marks, Mathieu \& Zaccaro, 2001) comprising of cognitive, emotional and affective components which signal to employees that knowledge sharing, both within and external to the unit, is valued and encouraged ( $\mathrm{Li}$, Shang, Liu \& Xi, 2014). We conceptualise internal to unit knowledge sharing as a work unit process involving behaviours such as giving feedback, discussing ideas and errors and identifying how tasks should be performed (Lin, 2007). The inclusion of both types of mediators potentially provides a deeper understanding of how TFL impacts work unit innovation performance (Lin, 2007; Bednall, Rafferty, Shipton, Sanders \& Jackson, 2018; Seung, Gaeun, Won Yoon \& Dong-Yeol, 2016).

Second, we address the relationship between TFL and innovation within work units rather that the organisation as a whole. Organisation-level studies potentially introduce greater organisational heterogeneity resulting in the potential for increased measurement error. These organisation-level studies assume there will be little or no variation in TFL within an organisation. Our sample highlights this diversity in business activities which potentially impacts leadership, the role and significance of innovation, and the importance of both the knowledge sharing climate and the knowledge sharing behaviours of unit members. To illustrate an organisation in our sample was classified in $\mathrm{NACE}^{1} 72.2$ but had units operating in 26.11 (Manufacture of electronic components); 47.41 (Retail sale of computers, peripheral units

\footnotetext{
${ }^{1}$ NACE is the The Statistical classification of economic activities in the European Community. The term NACE is derived from the French Nomenclature statistique des activités économiques dans la Communauté européenne. Various NACE versions have been developed since 1970 .
} 
and software in specialised stores); 47.42 (Retail sale of telecommunications equipment in specialised stores); and 58.2 (Software publishing). These different work units operate in different contexts and have different priorities for innovation. The investigation of the TFLinnovation link within the work unit therefore addresses this heterogeneity problem. We conducted our study within knowledge intensive business services firms (KIBS) (specifically classified under NACE 72, computer and related activities; 73 research and development, or 74 other business activities (European Commission, 2012). KIBS are an important context because of their contribution to innovation (Miles, Belousova \& Chichkanov, 2018) but we have insufficient understanding of the micro-level processes that contribute to the high levels of innovation in KIBS.

Third, we investigate the transformational leadership behaviours of leaders that operate at lower levels in organisational hierarchies and who are embedded in innovation processes rather than being above the fray. They operate in what Carter, Armenakis, Field \& Mossholder (2012) refer to as 'the trenches' where innovation is an integral part of on-going operations. This level of leadership in organisations is not the traditional focus of studies of the TFLinnovation relationship. There is an assumption that transformational leaders have the capacity to challenge the status quo and overcome organisational inertia. While this is something which upper echelon leaders have more scope to do (Chen et al., 2014), it may not be the case for unit level leaders.

The remainder of our article is structured as follows. We begin by reviewing the literature on TFL and innovation and developing our theoretical framework and specific hypotheses. We describe our methodology involving a cross-lagged design with dyadic data collected from 124 work unit leaders and 644 within unit employees and we set out the analytical techniques employed in our analysis. We then present and discuss our findings. Finally we highlight some 
theoretical and managerial implications arising from our study, as well as limitations and directions for further research.

\section{THEORETICAL BACKGROUND}

\subsection{Unit-Level Transformational Leadership and Unit Innovation Performance}

Recent conceptualisations of TFL emphasise a dual-level model where TFL may be either group or individual level in focus. Group level TFL treats unit employees similarly and they have equal access to idealised influence and inspirational motivation. Dong et al. (2017: 441) defined group level TFL as consisting of behaviours where leaders "emphasise common ground, shared values and ideology among team members by articulating a compelling vision, constituting a role model for the team, and fostering acceptance of collective goals". These behaviours have the effect of toning down individual behaviours and goals and facilitate unit innovative performance by aligning unit employees' goals and values, and enhancing collective optimism, efficacy and identification with the work unit and its objectives (Bass \& Riggio, 2006). Empirical investigations provide construct validity evidence demonstrating that idealised influence and inspirational motivation influence team and organisational outcomes (Wu, Zhu \& Yang. 2010; Cai, Jia \& Li, 2017).

\section{[Insert Figure 1 about here]}

TFL research supports the proposition that leaders play an important role in facilitating innovation (Wang, Kim \& Lee, 2016; Zhang, Li, Ullrich \& van Dick, 2015). Indeed, scholars have described TFL as a set of leadership behaviours that support innovation (Bono \& Judge, 2004). We argue, consistent with COR, that unit members with greater resources derived from idealised influence and inspirational motivation are more capable of orchestrating resource gains to achieve unit innovation. These TFL behaviours provide unit members with more 
opportunities to share ideas, and to take actions in conditions of uncertainty. Therefore, TFL as a contextual resource will - in a time-lagged way - influence work unit innovation. From a COR perspective, work unit leaders who demonstrate TFL behaviours convey a purposeful vision and provide inspirational motivation to unit employees which enhance the innovation performance of the unit. A clear vision is highlighted as essential for innovation performance and when leaders communicate such a vision around innovation, it stimulates unit employees to both generate and implement innovative ideas. These TFL resources will enable employees to collectively implement innovations within the work unit. Where TFLs create a compelling vision concerning innovation and they are viewed by unit employees as embodying and practicing this vision, they can stimulate unit innovation performance. Idealised influence emphasizes the degree to which the leader of the unit is admired, respected, dynamic and attentive. Unit leader idealised influence and inspirational motivation provide resources that help unit employees to cope with the risk of innovative actions (Bass, Avoilio, Jung \& Berson, 2003), reduce the complexity of innovation implementation, empower unit employees to challenge existing products and service weaknesses and secure successful implementation of new or adapted products/services. The provisions of resources through idealised influence and inspirational motivation helps stimulate work unit employees to think more deeply about the implementation of new products and services. In particular, inspirational motivation helps unit employees to look at new ways of doing things and enhances their motivation to continue with the process of implementation when they encounter challenges. It also helps unit employees to work cooperatively to implement innovations. Innovation is a highly risky, uncertain and cognitively taxing activity (Janssen, Van de Vliert \& West, 2004) and it requires a significant investment in energetic resources from unit members, often in situations of uncertainty. Unit leaders' inspirational motivation and idealised influence behaviours help unit members accumulate valuable resources for innovation and be less susceptible to resource depletion. 
They are more likely to experience a positive gain spiral (Hobfoll, Freedy, Lane \& Geller, 1990) which enhances their beliefs that they have the opportunity, autonomy and capability to achieve unit innovation outcomes. Arising from these arguments, our first hypothesis is as follows:

Hypothesis 1: Unit-level TFL will be positively related to work unit innovation performance.

\subsection{Unit Level Transformational Leadership, Unit Knowledge-Sharing Climate and Internal to Unit Knowledge Sharing}

We propose that TFL is positively related to unit knowledge sharing climate which, in turn, is positively related to unit knowledge sharing (García-Morales, Llorens-Montes \& Verdu-Jover, 2008). Unit knowledge sharing climate serves as a mediator linking TFL to internal to unit knowledge sharing. Knowledge sharing climate is normative and emergent and it impacts internal to unit knowledge sharing rather than unit innovation performance (Carmeli \& Azeroual, 2009; Jiang \& Chen, 2018). Internal to unit knowledge sharing represents behaviour that is more specific and, therefore, more relevant to innovation performance. Borrowing from COR theory, we propose that idealised influence and inspirational motivation are a contextual resource that facilitates the emergence of a unit knowledge sharing climate, another contextual resource located in the psychological environment of the work unit ( Brummelhuis \& Bakker, 2012). Therefore, unit leaders who display inspirational motivation and idealised influence create positive perceptions of the knowledge sharing climate. Unit leaders who demonstrate these behaviours are more likely to be perceived as trustworthy, to have a high quality vision for the work unit and to be viewed as role models which, in turn, inspire work unit employees' beliefs that unit leaders support knowledge sharing behaviours and actions. Zohar and Tenne-Gazit (2008) for example empirically demonstrated that TFL 
was positively associated with the strength of a work unit's safety climate. The unit leader becomes a major source of information about what is valued, prioritised and supported in the context of knowledge sharing. Over time these perceptions become shared because of the consistency of the work unit leader's messaging and will come to express a common perception that knowledge sharing is valued. These TFL behaviours are homogenous across the work unit because they are directed at the work unit as a whole and are observable to all employees (Shamir, Zakay, Breinin \& Popper (2000). Knowledge sharing climate as a resource includes positive cognitions concerning autonomy and power to engage in knowledge sharing and beliefs that employees can engage in knowledge-sharing behaviours without fear of sanction. It also includes both cognitions that knowledge sharing is a productive and worthwhile activity, and perceptions of their being positive emotional support for knowledge sharing (Husted \& Michaelova, 2002).

The TFL behaviours of idealised influence and inspirational motivation therefore, create another work unit resource - unit knowledge sharing climate - which is in turn linked to internal to unit knowledge sharing. Internal to unit knowledge sharing represents a collaborative process where all unit employees collectively work towards common goals (Boland \& Tenkasi, 1995). It includes the exchange of knowledge, expertise, experiences and skills throughout the work unit (Lin, 2007), the provision or receipt of task information, the giving and receiving of feedback, discussion of work problems collaboratively and identifying novel ways of doing things. Work unit knowledge sharing climate will therefore contribute to internal unit knowledge sharing for a number of reasons. First, it will help unit employees to be more energised, to share knowledge and support colleagues who share knowledge and to better cope with the demands associated with internal to unit knowledge sharing. Second, it will help unit employees to collectively agree expectations and demonstrate the behaviours that will support internal to unit knowledge sharing. Third, knowledge sharing sometimes 
involves risks, therefore, a strong knowledge sharing climate helps remove or reduce concerns related to any perceived potential downsides of knowledge sharing. Based on these arguments, our second hypothesis is as follows:

Hypothesis 2: Unit level TFL will be positively associated with internal to unit knowledge sharing through knowledge sharing climate.

\subsection{Unit Knowledge Sharing Climate, Internal to Unit Knowledge Sharing and Unit Innovation Performance}

We propose that unit knowledge sharing climate is linked to unit innovation performance through internal to unit knowledge sharing. Unit knowledge sharing climate as a contextual resource will have a motivational effect on the knowledge sharing behaviours of the work unit because it provides the context within which work unit employees can debate ideas, share tacit and explicit knowledge and discuss more effective ways of doing things. The resources derived from a positive knowledge sharing climate help work unit employees to address the challenges that come with innovation.

We theorise that the effects of unit knowledge sharing created through the unit-level TFL and knowledge sharing climate contextual resources on unit innovation performance may not accrue simultaneously as knowledge is shared within the work unit. Therefore, there will be a timelagged effect on unit innovation. The process of work unit knowledge sharing helps unit employees to work communally to develop and implement innovative solutions. The interactions that occur among employees enhance the ability of the work unit to develop new unit knowledge crucial for innovation performance (Stephens \& Carmeli, 2016). Where unit employees collectively share tacit knowledge, different perspectives are surfaced that can then be converted into new products and services. Because innovation is a collaborative process (Burns, 2013), the sharing of tacit knowledge by work unit employees represents an important 
requirement for work unit innovation performance. Based on these arguments our third hypothesis is as follows:

Hypothesis 3: Unit knowledge sharing climate will be positively associated with work unit innovation performance through internal to unit knowledge sharing.

\subsection{The Mediating Role of Both Unit Knowledge-Sharing Climate and Internal to Unit Knowledge Sharing}

Building on hypotheses 2 and 3, we argue that unit level idealised influence and inspirational motivation exert a positive influence on unit innovation performance via their effects on unit knowledge sharing climate and internal to unit knowledge sharing. These TFL behaviours serve as a contextual resource, leading to the development of unit knowledge sharing climate, another contextual resource, which in turn, leads to unit innovation performance through unit knowledge sharing. The purposeful vision of the unit leader concerning innovation, and the provision of inspirational motivation, leads to the emergence of a positive knowledge sharing climate. The resources associated with a positive knowledge sharing climate leads to unit knowledge sharing which impacts unit innovation performance. Therefore, we propose our fourth and final hypothesis as follows:

Hypothesis 4: The relationship between unit TFL and unit innovation performance will operate through the double mediation of unit knowledge-sharing climate and internal to unit knowledge sharing.

\section{METHODOLOGY}

\subsection{Participants and Procedure}

We derived the population of work units located in the UK using the Dun and Bradstreet Global 
Reference Solution (GRS) Database, one of the most comprehensive and detailed sources for information on organisations (see Henriques, 2014).We utilised four criteria to derive a stratified sample: (1) the 'global ultimate controlling company' was in the UK (the UK ownership criteria was used to eliminate potential 'country of origin' effects); (2) Units had to operate within the 'knowledge-intensive' business services sector (KIBS) (specifically NACE 72, computer and related activities; 73 research and development, or 74 other business activities (European Commission, 2012); (3) each unit had to employ between 10-249 employees; and (4) in order to reduce idiosyncratic start-up effects, each unit had to be in operation for at least 18 months. A final criterion, following on from the randomly generated sample, was that if a unit was part of a larger organisation, only one unit per organisation was included.

Letters and emails were sent to the unit leader identified from the Dun and Bradstreet GRS database. A professional survey company (ISO 9000 certified) conducted the structured interviews with the unit's leader, which lasted approximately 40 minutes, in both time periods (2010 and 2013). During the interviews at Time 1, we sought agreement from the unit leader to survey by email all of the unit employees (other than administrative and manual supports). The surveys were administered through a password protected university email account administered by the PI and prospective respondents were also assured of anonymity.

The response rates were as follows: 32.9 per cent of unit leaders identified participated in 2010 (1,764 responses); of this pool of respondents, 55.9 per cent agreed to allow their employees to be surveyed, which reduced the sample to 937 units in which the collection of dyadic data was possible. Unit leaders were only approached to participate in 2013 (Time 2) if a minimum of 5 employees within the unit (Kreft \& de Leeuw, 1998) had completed the survey and where the unit leader and employees were the same individuals who had completed the survey in 2010. These criteria reduced the number of units approached in Time 2 to 286 and of which 165 interviews (57.7 per cent) were successfully completed. Due to missing and 
incomplete data, our final sample comprises 124 units and 644 employees. We have only included these two-wave multi-respondent data in our analysis in order to ensure our data were balanced.

Given the two-wave nature of our study, we paid particular attention to ensuring that in the intervening period between round one and round two of our data collection, no significant changes had occurred within the unit and in our round two interviews with the unit managers we explored this as part of our follow-up. We used two tests to examine whether the attrition between the two time periods was random: attrition probits (Fitzgerald, Gottschalk \& Moffitt, 1998) and pooling tests, in which the equality of coefficients from the baseline sample with and without attritors are equal (Becketti, Gould, Lillard \& Welch, 1988). Baulch and Quisumbing (2010) Stata coding for attrition was adapted. Neither test found any statistically significant evidence of non-randomness in the characteristics of units with attrition over the two sample periods. All regression results were also run separately for units with attrition and units without attrition. No statistically significant results were found between these two cohorts (results are available upon request). ${ }^{2}$

The characteristics of the sample work units were as follows: The average total unit employment was 83.8 and the average age was 17.8 years (the logarithms of these variables are used in all subsequent analysis). The probability that a unit is part of a larger organisation increases with unit size. Sixty-one per cent of sample units were single-site. Fifty-nine per cent of sample units innovated in $t=1$ (2010) and 63.8 per cent in $t=2$ (2013). By way of comparison, the Community Innovation Survey (CIS) results found that 53 per cent of UK businesses innovated in 2015 (BIS, 2016).

\footnotetext{
${ }^{2}$ Given that our units operated in the 'knowledge-intensive' business services sector (KIBS), innovation was particularly important to the units included in our study (Desyllas, Marcela, Hsing-fen \& Miles, 2018; Boix, De-Miguel-Molina, \& Hervas-Oliver, 2013)). Each unit was geographically dispersed; they offered a variety of services to customers and they had to develop product and service innovations to meet the needs of customers to achieve business targets. They operated in markets and environments of varying dynamism and competitiveness, therefore, it was imperative to pursue both product and service innovation.
} 
The characteristics of our respondents were as follows: Seventy-three per cent of unit leaders and 67.9 per cent of employees were male; 65.4 per cent and 49.9 per cent respectively held a Master's degree or higher; The average age of unit leaders was 36.5 years $(S D=3.87)$ and was 30.06 years $(S D=5.72)$ for employees; The average tenure for unit leader was 53.17 months $(S D=30.36)$ and for employees was 37.45 months $(S D=32.66)$.

\subsection{Measures}

All perceptual items were measured using a five-point scale $(1=$ strongly disagree; $5=$ strongly agree). Table A1 in Appendix 1 provides details of the scale items used in the study.

Unit Level Transformational Leadership (TFL): Unit employees assessed unit level TFL at Time 1. We adapted four items from the García-Morales et al. (2008) TFL scale to measure idealised influence and inspirational motivation. We asked unit employees to assess the TFL of the focal leader (i.e., the unit leader) on both dimensions. Sample items included: "The unit leader succeeds in motivating and guiding unit employees on the job" and "The unit leader always acts as the unit's leading force". We followed the two-stage procedure recommended by Anderson \& Gerbing (1988) of first conducting exploratory factor analysis (EFA) and then in stage two, we estimated the measurement model using confirmatory factor analysis (CFA) to test the goodness of fit of the measurement scales (Anderson \& Gerbing, 1988; Fornell \& Larcker, 1981). The EFA results, which are shown in Table A 1 (Appendix), indicate that all four items loaded onto one factor with an eigenvalue of 5.36 and explained 80.23 per cent of the variability, with factor loadings ranging from 0.85 to 0.89 . In step two, using confirmatory factor analysis $\left(X^{2}=791.44 ., d f=326 ; p<0.001\right.$; robust $\mathrm{RMSEA}=0.043$; robust $\mathrm{CFI}=0.982$; robust $\mathrm{TLI}=0.976$, we validated the scale and we then found that it was unidimensional and reliable $(\alpha=0.873)$ (see Table 1 for results for each variable). 
Unit Knowledge Sharing Climate (KSC): Unit employees assessed unit knowledgesharing climate at Time 1. We utilized a 4-item scale adapted from Husted \& Michailova (2002) modified to the work unit level of analysis. Sample items included: "Time spent on knowledge sharing is generally time well spent" and "Unit employees do not consider knowledge sharing to be risky because unit employees are generally open to new ideas". Results of the exploratory factor analysis indicate that the four items loaded onto one factor with an eigenvalue of 4.52 and explained 41.22 per cent of the variability, and had factor loadings from 0.83 to 0.88 . Using confirmatory factor analysis $\left(X^{2}=744.06, d f=314 ; p<0.001\right.$; robust RMSEA $=0.042$; robust CFI $=0.993$; robust $\mathrm{TLI}=0.985)$, we validated the scale and we then found that it was unidimensional and reliable $(\alpha=0.923)$.

Internal to Unit Knowledge Sharing (IKS): Following previous research (Lee 2001; Lu, Leung \& Koch, 2006), eight items were used to assess the extent to which employees exchange knowledge with colleagues inside of the work unit. Respondents were asked to indicate on a five-point scale (ranging from $1=$ not at all to five $=$ to a large extent) the degree to which they exchanged knowledge with both their colleagues inside the work unit (i.e., internal knowledge sharing) and people outside of the unit (i.e., external knowledge sharing). Sample items included: "Unit employees regularly access colleagues and exchange new ideas and developments with them". The exploratory factor analysis found that the eight items loaded onto one factor with an eigenvalue of 6.23 and explained 78.55 per cent of the variability. Using confirmatory factor analysis $\left(X^{2}=830.42, d f=319 ; p<0.001\right.$; robust RMSEA $=0.034$; robust CFI $=0.980$; robust TLI $=0.972$ ) we validated the scale and we found that it was unidimensional and reliable $(\alpha=0.893)$.

\section{Dependent Variable}


Unit Innovation Performance (IPerf): Following Churchill (1979) and LópezCabrales, Pérez-Luno \& Valle Cabrera (2009), we utilised an eight item scale. Here, unit leaders assessed unit innovation performance at Time 1 and Time 2. At Time 1 they reported on innovation in the three previous years. We then re-measured innovation after a three-year interval. This timeline is consistent with those used in surveys of innovation (e.g., Community Innovation Survey (CIS), 2013). This measure operationalises innovation into product/service and process innovation efficiency. The exploratory factor analysis resulted in the elimination of two items ( 3 and 4 , as they fell below the recommended 0.5 cut-off for exploratory factor analysis). In T1, the remaining six items loaded onto one factor with an eigenvalue of 5.91 and explained 73.29 per cent of the variance; in $\mathrm{T} 2$, the six items loaded onto one factor with an eigenvalue of 5.93 and explained 73.44 per cent. Subsequent confirmatory factor analyses (Time 1: $X^{2}=124.62, d f=36 ; p<0.001$; robust $\mathrm{RMSEA}=0.032$; robust $\mathrm{CFI}=0.982$; robust $\mathrm{TLI}=0.976 ;$ Time $2: X^{2}=120.83, d f=36 ; \mathrm{p}<0.001 ;$ robust $\mathrm{RMSEA}=0.031 ;$ robust $\mathrm{CFI}=$ 0.991; robust $\mathrm{TLI}=0.983$ ) revealed that the scale at both time points was unidimensional and reliable $(\alpha=0.823$ in T1 and $\alpha=0.857$ in T2)

\section{Control Variables}

We employed several controls as recommended in recent reviews of control variable usage (Bernerth, Cole, Taylor \& Walker, 2018; Bernerth \& Aguinis, 2016). Human capital and resource characteristics may impact the innovation of a unit (Blundell, Dearden, Meghir $\&$ Sianesi, 2005). We therefore controlled for the education of both respondent groups $(0=$ less than university; 1 = university; $2=$ Masters, $3=\mathrm{PhD}$ ). We summed these values across each respondent in a unit and calculated the median to measure a unit's overall median level of education. We also controlled for unit size (log of unit size), unit age (log of unit age) (Jung, Chow \& Wu, 2003), unit financial performance (log profit per employee) and Time 1 innovation. We controlled for the potential effects of subsectors (NACE 72, 73, 74). We 
followed the sample design used by the UK's Work Employment Relations Survey (WERS) (Chaplin, Mangla, Purdon \& Airey, 2005) whereby the primary sampling unit is the workplace local unit with all having a significant need to utilise knowledge in order to develop customised service or product solutions to satisfy client needs (Desyllas, Marcela, Hsing-fen \& Miles, 2018). Following WERS protocol and whether the unit is a multi-sited workplace or part of a larger organisation is controlled for in the estimations ('single-site'). Given the potential for multicollinearity among the control variables, the base model, was first estimated by Lasso regression to perform variable selection. ${ }^{3}$ The three NACE subsector coefficients were zero whereas all other control variable coefficients were non-zero. Thus, only the NACE subsector control variables are not included in the estimations presented.

\section{RESULTS}

[Insert Table 1 about here]

Table 1 reports the correlation matrix. We checked for multicollinearity. The correlation matrix indicates that the data do not suffer from multicollinearity since all of the correlations are equal to or below 0.68. Kline (2005) suggests that indications of substantial multicollinearity arise with correlations above 0.85 . In addition, the variance inflation factors (VIF) in each regression equation were low-ranging from 1.09 to 1.94 - well below the lower end of the recommended threshold of 4 - 5 in the literature of (Rogerson, 2001) (In Appendix 2 we report on the suite of tests we conducted for sample representativeness, construct validity and model fit, data quality and data aggregation).

\footnotetext{
${ }^{3}$ Our estimations in R were guided by Thevaraja, Rahman \& Gabirial (2019).
} 


\subsection{Hypothesis Testing}

To reduce the potential for multicollinearity, we mean-centred the individual variables before calculating the interaction terms. Table 2 presents the results of the hierarchical multiple regression analysis. First, Model 1 presents the analysis for the control variables.

[Insert Table 2 about here]

We found that Time 1 innovation performance, financial performance and median employee education were all significantly related to innovation at Time $2(\beta=0.127, p<0.01$; $\beta=0.106, p<0.05$ and $\beta=0.167, p<0.01$; Table 2 , Model 1), respectively.

Hypothesis 1 proposed a direct association between unit-level TFL and unit innovation performance. We found that unit level TFL in Time 1 is positively related to unit innovation performance in Time $2(\beta=0.372 ; p<0.001$; Model 2$)$. We, therefore, find support for hypothesis 1.

Our second hypothesis proposed that unit knowledge sharing climate will mediate the relationship between unit-level TFL and internal to unit knowledge sharing. We found that unit level TFL is positively related to unit knowledge-sharing climate $(\beta=0.321 ; p<0.001$; Model 3). Unit-level TFL is positively associated to internal to unit knowledge sharing $((\beta=0.478 ; p$ $<0.001$; Model 4) and unit knowledge sharing climate is positively associated with internal to unit knowledge sharing $(\beta=0.516 ; p<0.001$; Model 4$)$. When we added unit knowledge sharing climate into the model, the size of the unit-level TFL-internal to unit knowledge sharing association was reduced $(\beta=0.289 ; p<0.01$; Model 5; down from $\beta=0.478 ; p<0.001)$. The Sobel test revealed that the indirect effect of unit level TFL on internal to unit knowledge sharing through unit knowledge sharing climate was significant (Sobel test: $z=2.58 ; p<0.01$ ). Therefore, with respect to hypothesis 2 , knowledge sharing climate is found to partially mediate the relationship between unit-level TFL and internal to unit knowledge sharing.

Hypothesis 3 proposed that internal to unit knowledge sharing will mediate the 
relationship between unit knowledge sharing climate and unit innovation performance. We found that knowledge sharing climate is positively related to innovation performance $(\beta=$ $0.273 ; p<0.01$; Model 6) and internal to unit knowledge sharing is positively related to innovation performance $(\beta=0.471 ; p<0.001 ;$ Model 7$)$. We also found that knowledge sharing climate is positively related to internal to unit knowledge sharing $(\beta=0.511 ; p<0.001$; Model 5). When we added internal to unit knowledge sharing into the model, the size of the knowledge sharing climate-innovation performance association was reduced $(\beta=0.197 ; p<0.05$; Model 8 ; down from $\beta=0.273 ; p<0.01$ ). The Sobel test showed the indirect effect of knowledge sharing climate on innovation performance through internal to unit knowledge sharing $(z=$ 4.22; $p<0.001)$.

Finally, hypothesis 4 proposed a double mediation of unit level TFL and unit innovation performance through both knowledge sharing climate and internal to unit knowledge sharing. Model 2 shows the significant relationship between unit level TFL and unit innovation performance; Model 3 shows the significant relationship between unit level TFL and knowledge sharing climate; Model 4 shows the significant relationship between unit level TFL and internal to unit knowledge sharing; Models 5 and 6 show the significant relationships between unit knowledge sharing climate and internal to unit knowledge sharing and innovation performance respectively (fulfilling Baron \& Kenny's (1986) first three necessary criteria to validate mediation effects). The fourth step, involving the adding of the proposed mediators unit knowledge sharing climate and internal to unit knowledge sharing - reduces the strength of the relationship between unit level TFL and unit innovation performance to $(\beta=0.216 ; p<$ 0.05; Model 9 (knowledge sharing climate as the mediator) and to $(\beta=0.253 ; p<0.01$; Model 10 (internal to unit knowledge sharing as the mediator) (the coefficient for TFL down from $\beta$ $=0.372 ; p<0.001$, Model 2), thus indicating partial mediation and supporting hypothesis 4 . Model 11 adds both mediators together and, again, evidence is found for partial mediation (the 
coefficient for TFL becomes $\beta=0.219 ; p<0.005)$.

Given the assumption of normality of the sampling distribution of the total and specific indirect effects is questionable and because there is limited consensus on how to test for more than one mediator, particularly in small samples (Preacher \& Hayes, 2008), we bootstrapped the indirect effects of unit level TFL on innovation performance, using the PROCESS regression-based macro (v3.1) (2018) ran in SPSS version 22 (see Hayes, 2013). Results of the bootstrapping for the individual mediators further support the Sobel tests at the bootstrapped 95 per cent confidence intervals for each of the indirect effects tested. (Results of the bootstrapping procedure are available from the first author upon request). The product of coefficients estimates indicates that both proposed mediators are significant (see columns 1-3; Table 3). The examination of the specific indirect effects using 5,000 bootstrapping samples with both 95 per cent bias-corrected and bias-corrected-accelerated confidence intervals also provide support for knowledge sharing climate and internal to unit knowledge sharing as mediators since none of the 95 per cent CIs contain zero (see columns 4-7).

[Insert Table 3 about here]

\section{DISCUSSION}

Innovation is a major strategic priority for knowledge intensive firms, however, they frequently struggle in achieving innovation outcomes (Boatman \& Wellins, 2011). In this study we utilised COR theory to theorise the impact of two ambient focused unit level TFL behaviours on unit innovation performance and we gathered time-lagged, dyadic data to test our hypotheses: First, we found that unit level TFL was positively associated with unit innovation performance. Second, we found that unit level TFL was linked to unit knowledge sharing climate and in turn, to unit knowledge sharing, which then lead to unit innovation performance. Based on these findings, we conclude that the link between unit level TFL behaviours and unit innovation performance is partially mediated. 


\subsection{Theoretical Contributions}

Drawing on the intellectual utility of COR theory to understand the role of two ambient TFL behaviours and their link to innovation in work units, our study makes important theoretical and empirical contributions. First, we found a direct link between TFL (idealised influence and inspirational motivation) as a contextual resource and innovation performance in work units. These ambient focused TFL behaviours are valued by unit members as an important contextual resource which helps them to achieve innovation outcomes. Employees in work units will derive resources from these TFL behaviours because they are collectively focused and as a consequence they obtain additional new resources and achieve "positive gain spirals" (Hobfoll, 2011).

Second, our study advances aspects of the TFL literature by examining the mediating mechanisms underlying the relationship between TFL and unit innovation. Drawing on arguments from COR theory, we investigated the mediating role of knowledge sharing climate between TFL and unit knowledge sharing. In pursuing this line of inquiry, we found that when unit members experience strong ambient TFL behaviours and are supported by a strong knowledge sharing climate they will possess valuable resources to engage in unit knowledge sharing. Acquiring such resource caravans ultimately enhances unit knowledge sharing which leads to unit innovation. Therefore, our finding addresses a research gap highlighted by Gumusluoglu \& Ilsev (2009) and Rosing et al. (2011) who recommended that more research should investigate the processes that mediate the link between TFL and innovation. Crossan \& Apaydin (2010) also suggested that research on the linkages between TFL and innovation needed deeper investigation. Taking up the challenge methodologically we have sought to unearth the TFL-innovation link by controlling for T1 unit innovation performance, by separating the predictor (TFL) and outcome (innovation performance) time wise and by gathering data from two sources. The lack of time-lagged research designs is highlighted as a 
specific weakness in the literature (Rosing et al., 2011). Our study design reduces concerns about common method bias (Podsakoff, MacKenzie \& Podsakoff, 2012) and enhances the validity of our findings.

Finally, in investigating the link between TFL and innovation performance in a work unit context within knowledge intensive firms, we have responded to calls highlighting the need to pay attention to levels of analysis issues when investigating the TFL-innovation relationship. The work unit is an important feature of modern organisations and such units represent a distinct level of analysis (Wang \& Howell, 2012). From a measurement perspective, the use of the work unit has a significant methodological advantage in that it helps to avoid some of the significant heterogeneity that may arise when investigating TFL and innovation at the organisational level.

\subsection{Implications for Practice}

Because the use of work units with an innovation remit is likely to increase in the future, the importance of TFL as a means to unlock work unit innovation performance is also likely to increase. There is, therefore, a need for organisations to pay attention to the prospective role of TFL in enhancing work unit innovation. Our results suggest that it makes sense for organisations to be mindful of how they select and develop business unit leaders to demonstrate idealised influence and inspirational motivation behaviours. They should, for example, use selection criteria and selection methods that assess whether unit managers have the potential to demonstrate ambient TFL behaviours. In terms of development, organisations should implement multisource feedback processes, feedback intensive programmes and provide coaching and mentoring development processes to support leaders to demonstrate TFL behaviours. Unit leaders should also have development around communication processes to effectively communicate norms about knowledge sharing and their support for knowledge sharing to their employees, and the building of a strong climate of knowledge sharing more broadly. 
Our results offer insights into how work unit transformational leaders influence work unit innovation performance. The significant role of knowledge sharing climate and internal to unit knowledge sharing in this context provides organisations with opportunities concerning the fostering of innovation in work units. In particular, unit leaders could augment their TFL behaviour efforts by fostering a climate that supports knowledge sharing and, in this regard, our findings suggest that managers in the first instance need to focus their efforts on creating a climate within the work unit that is conducive to knowledge sharing. Efforts dedicated to creating positive organisational norms around knowledge sharing may yield significant benefits in terms of knowledge sharing. It is, therefore, critical for managers to appreciate the strategies and tactics that they can use to create these norms. This task should be less complex in the work unit context because work units tend to be less expansive and hierarchical and, as a consequence, unit leaders have greater potential through TFL behaviours to exert a direct influence on knowledge-sharing norms. Knowledge sharing could also be incentivised if embedded in performance management metrics.

\subsection{Strengths, Limitations and Future Research Agenda}

We make a significant contribution to the literature by employing arguments from COR theory to investigate the link between ambient TFL behaviours demonstrated by work unit leaders in achieving innovation outcomes in knowledge intensive firms. Although our study utilised a time-lagged design Ployhart \& Vanderberg (2010) caution that in order to detect real change and differentiate it from measurement error, it is necessary to measure study variables three or more times. Therefore, researchers could usefully build on our result by using three or more collection points. In addition, additional longitudinal investigations could enable researchers to investigate the reciprocal nature of the TFL- innovation relationship and to understand the role that high levels of unit innovation performance have on subsequent TFL 
behaviours and vice versa. A longer time period would also help to eliminate any potential for reverse causality.

We measured unit level TFL (predictor), and both mediators - internal to unit knowledge sharing and unit knowledge-sharing - climate with data from the same respondents, thus raising the possibility of common method variance bias. We used Harmon's one factor test for these variables but did not find a single factor that accounted for the majority of the variance in the independent variable. Were common method variance an issue, we would likely have found that a single factor would have emerged or one general factor would account for the majority of variance (Podsakoff \& Organ, 1986). Given that we used self-report measures of innovation, we were able to cross-validate the unit managers' responses on innovation with just over half of units that had R\&D specialist reports on innovation performance. We found no statistically significant differences within these units between unit leader's and R\&D specialists' responses on the innovation items. We are also conscious that, given that the time interval between Time 1 and 2 was three years, this potentially gives rise to issues of membership stability within the units' studies. This was significantly mitigated in our study by only including units at Time 2 where the unit leader and employee respondents were the same as in Time 1 . We also checked whether the size of the unit had changed significantly in the intervening period.

Furthermore, our study did not investigate the influence of other forms of leadership including authentic, charismatic, ethical, inspirational, transactional, or indeed management innovation (Salas-Vallina, Simone \& Fernández-Guerrero, 2018; Volberda, Van den Bosch \& Heij, 2013). Therefore, future research could usefully investigate the explanatory power of different forms of leadership in the work unit context and whether the mediation mechanisms revealed in our study would hold up. There is also scope to investigate how collective perceptions of unit knowledge-sharing climate emerge, develop and are maintained and on how phenomena emerge within organisations (Kozlowski, Chao, Grand, Braun \& Kuljanin, 2013). 
Additional unit contextual factors may also be relevant as potential mediators of the links found in our study including for example work processes, the number of opportunities for unit employees to interact with each other and the competitive pressures on the unit, each of which may impact how and at what pace the perceptions that were the focus of our study become collective ones.

\section{CONCLUSION}

Using a cross-lagged research design, we tested the influence of TFL (idealised influence and inspirational motivation) on work unit innovation. Employing ideas from COR theory to frame our argument and build our model, we propose a double mediation mechanism where TFL leads to the development of a knowledge sharing climate which, in turn, enhances knowledge sharing within the work unit, and leads to innovation. Overall, our empirical results point to the value of seeking to unearth work unit focused TFL behaviours as requisites for innovation gains and we identify a number of attendant directions for future research in order to open up new lines of inquiry on the TFL innovation relationship. 


\section{References}

Anderson, J. C., \& Gerbing, D. W. (1988). Structural equation modelling in practice: A review and recommended two-step approach. Psychological Bulletin, 103(3), 411-423. https://dx.doi.org/10.1037/0033-2909.103.3.411.

Baer, M. (2012). Putting creativity to work: The implementation of creative ideas in organizations. Academy of Management Journal, 55, 1102-1119. https://doi.org/10.5465/amj.2009.0470.

Baron, R.M., \& Kenny, D.A. (1986). The moderator-mediator variable distinction in social psychological research: Conceptual, strategic, and statistical considerations. Journal of Personality and Social Psychology, 51(6), 1173-1182. https://dx.doi.org/10.1037/00223514.51.6.1173.

Bass, B.M., Avoilio, B.J., Jung, D.I., \& Berson, Y. (2003). Predicting unit performance by assessing transformational and transactional leadership. Journal of Applied Psychology, 88(2), 207-218. https://dx.doi.org/10.1037/0021-9010.88.2.207.

Bass, B.M. \& Riggio, R.E. (2006). Transformational Leadership. (2 ${ }^{\text {nd }}$ ed.). New York. Psychology Press.

Baulch, B. \& Quisumbing, A. (2010) Testing and adjusting for attrition in household panel data. Toolkit Note. Chronic Poverty Research Centre. UK: London.

Retrieved from: http://www.chronicpoverty.org/uploads/assets/files/toolbox/CPRC TOOLKIT_NOTE _ON_ATTRITION-revfinal.pdf. Accessed February 2019.

Becketti, S., Gould, W., Lillard, L. \& Welch, F. (1988). The panel study of income dynamics after fourteen years: An evaluation. Journal of Labor Economics, 6, 472-492.

Bednall, T. C., Rafferty, A., Shipton, H., Sanders, K., \& Jackson, C. (2018). Innovative behaviour: how much transformational leadership do you need?. British Journal of Management, 29, 796-816. https://doi.org/10.1111/1467-8551.12275.

Bernerth, J.B. \& Aguinis, H. (2016). A critical review and best-practice recommendations for control variable usage. Personnel Psychology, 69, 229-283. https://doi.org/10.1111/peps.12103.

Bernerth, J.B., Cole, M.S., Taylor, E.C., \& Walker, H.J. (2018). Control variables in leadership research: A qualitative and quantitative review. Journal of Management, 44, 131-160. https://doi.org/10.1177/0149206317690586. 
Blank, S. (2013). Why the lean start-up changes everything. Harvard Business Review, 91, 6372. Retrieved from: https://hbr.org/2013/05/why-the-lean-start-up-changes-everything. Accessed February 2019.

Blundell, R., Dearden, L., Meghir, C. \& Sianesi, B. (2005). Human capital investment: The returns from education and training to the individual, the firm and the economy. Fiscal Studies, 20, 1-23. https://doi.org/10.1111/j.1475-5890.1999.tb00001.x.

Boatman, J., \& Wellins, R. S. (2011). Global leadership forecast 2011: Time for a leadership revolution. Development Dimensions International. Retrieved from: https://www.ddiworld.com/ddi/media/trendresearch/globalleadershipforecast2011_globalreport_ddi.pdf. Accessed January 2019.

Boix, R., De-Miguel-Molina, B. \& Hervas-Oliver, J.L. (2013). Creative service business and regional performance: evidence for the European regions. Service Business, 7, 381-398. https://DOI: 10.1007/s11628-012-0165-7.

Boland, Jr, R.J. \& Tenkasi, R.V. (1995). Perspective making and perspective taking in communities of knowing. Organisation Science, 6, 350-372.

Bono, J.E. \& Judge, T.A. (2004). Personality and transformational and transactional leadership: a meta-analysis. Journal of Applied Psychology, 89, 901-910. https://dx.doi.org/10.1037/0021-9010.89.5.901

Brown, B., \& Anthony, S. D. (2011). How P\&G tripled its innovation success rate. Harvard Business Review, 89, 64-72. Retrieved from: https://hbr.org/2011/06/how-pg-tripledits-innovation-success-rate. Accessed January 2019.

Brummelhuis, L. L ten. \& Bakker, A. B. (2012). A resource perspective on the work-home interface: The work-home resources model. American Psychologist, 67, 545-566. https://doi: 10.1037/a0027974.

Burns, A. (2013). Innovation through action research and teacher-initiated change. In K. Hyland \& L.C. Wong (Eds.) Innovation and change in English language education (pp. 106121). Abingdon: Routledge.

Cai, Y., Jia, L. \& Li, J., (2017). Dual-level transformational leadership and team information elaboration: The mediating role of relationship conflict and moderating role of middle way thinking. Asia Pacific Journal of Management, 34(2), 399-421. https://dx.doi.org/10.1007/s10490-016-9492-X.

Carter, M.Z., Armenakis, A.A., Feild, H.S. \& Mossholder, K. W. (2012). Transformational leadership, relationship quality, and employee performance during continuous incremental organisational change. Journal of Organisational Behavior, 34, 942-958. 
https://doi.org/10.1002/job.1824.

Carmeli, A. \& Azeroual, B. (2009). How relational capital and knowledge combination capability enhance the performance of work units in a high technology industry. Strategic Entrepreneurship Journal, 3, 85-103. https://doi.org/10.1002/sej.63.

Chaplin, J., Mangla, J., Purdon, S., \& Airey, C. (2005). The Workplace Employment Relations Survey 2004 (WERS 2004) Technical Report (Cross-Section and Longitudinal Surveys). London: National Centre for Social Research.

Chen Y., Tang, G., Jin, J., Xie, Q., \& Li, J. (2014). CEO’s Transformational leadership and product innovation performance: The roles of corporate entrepreneurship and technology orientation. The Journal of Product innovation Management, 31, 2-17. https://doi.org/10.1111/jpim.12188.

Chen, G., Mathieu, J. and Bliese, P. (2005). A Framework for Conducting Multi-level Construct Validation. In F. Yammarino \& F. Dansereau (Eds.) Multi-level Issues in Organizational Behavior and Processes (Research in Multi-Level Issues, Vol. 3) (pp. 273-303). Bingly: Emerald Group Publishing. https://doi.org/10.1016/S14759144(04)03013-9.

Chen, Jian-Xun, Sharma, Piyush, Zhan, Wu \& Liu, Li (2019). Demystifying the impact of CEO transformational leadership on firm performance: Interactive roles of exploratory innovation and environmental uncertainty, Journal of Business Research, 96, 85-96. https://doi: 10.1016/j.jbusres.2018.10.061.

Churchill, G.A. Jr. (1979). A paradigm for developing better measures of marketing constructs. Journal of Marketing Research, 16, 64-73. https://doi: 10.2307/3150876.

Clarkson, J. J., Hirt, E. R., Jia, L., \& Alexander, M. B. (2010). When perception is more than reality: the effects of perceived versus actual resource depletion on self-regulatory behavior. Journal of Personality and Social Psychology, 98, 29-46. http://dx.doi.org/10.1037/a0017539.

Community Innovation Survey (CIS) (2013). Retrieved from: https://ec.europa.eu/eurostat/web/microdata/community-innovation-survey. Accessed December 2018.

Consoli, D. \& Elche-Hortelano, D. (2010). Variety in the knowledge base of Knowledge Intensive Business Service. Research Policy, 39, 1303-1310.

Crossan, M.M. \& Apaydin, M. (2010). A multi-dimensional framework of organisational innovation: A systematic review of the literature, Journal of Management Studies, 47(6), 1154-1191. https://doi.org/10.1111/j.1467-6486.2009.00880.x.

Desyllas, P., Marcela, M., Hsing-fen, L. \& Miles, I. (2018). Capturing value from innovation in knowledge-intensive business service firms: The role of competitive strategy. British 
Journal of Management, 29(4), 769-795. https://doi.org/10.1111/1467-8551.12273.

Dong, Y., Bartol, K.M., Zhang, Z.X. \& Li, C. (2017). Enhancing employee creativity via individual skill development and team knowledge sharing: Influences of dual-level transformational leadership. Journal of Organisational Behavior, 38, 439-458. https://doi.org/10.1002/job.2134

Ehrhart, M.G., \& Naumann, S.E. (2004). Organisational citizenship behavior in work groups: A group norms approach. Journal of Applied Psychology, 89(6), 960-974.

https://dx.doi.org/10.1037/0021-9010.89.6.960.

European Commission (EC). (2012). Knowledge-intensive (business) services in Europe. Retrieved from:https://ec.europa.eu/research/innovationunion/pdf/knowledge_intensive_business _services_in_europe_2011.pdf. Accessed December 2018.

Fitzgerald, J., Gottschalk, P. \& Moffitt, R. (1998). An Analysis of Sample Attrition on the Second Generation of Respondents in the Michigan Panel Study of Income Dynamics. The Journal of Human Resources, 33(2), 300-334.

Fornell, C., \& Larcker, D. F. (1981). Structural equation models with unobservable variables and measurement error: Algebra and statistics. Journal of Marketing Research, 18, 382388.

García-Morales, V.J., Lllorens-Montes, F.J. \& Verdu-Jover, A.J. (2008). The effects of transformational leadership on organisational performance through knowledge and innovation. British Journal of Management, 19, 299-319. https://doi: 10.1111/j.14678551.2007.00547.x.

García-Morales, V.J., Jiménez-Barrionuevo, M.M., \& Gutiérrez-Gutiérrez, L. (2012). Transformational Leadership Influence on Organisational Performance through Organisational Learning and Innovation. Journal of Business Research, 65, 1040-1050. https://psycnet.apa.org/doi/10.1016/j.jbusres.2011.03.005.

García-Morales, V.J., Matias Reche, F., \& Hurtado Torres, N. (2008). Influence of transformational leadership on organisational innovation and performance depending on the level of organisational learning in the pharmaceutical sector. Journal of Organisational Change Management, 21, 188-212. https://doi.org/10.1108/09534810810856435.

Gumusluoglu, L. \& Ilsev, A. (2009). Transformational leadership, creativity, and organisational innovation. Journal of Business Research, 62(4), 461-473. https://doi: https://dx.doi.org/10.1016/i.jbusres.2007.07.032. 
Halbesleben, J. R. (2006). Sources of social support and burnout: a meta-analytic test of the conservation of resources model. Journal of Applied Psychology, 91, 1134-45.

Halbesleben, J. R., Neveu, J. P., Paustian-Underdahl, S. C., \& Westman, M. (2014). Getting to the "COR" understanding the role of resources in conservation of resources theory. Journal of Management, 40, 1334-1364. https://doi.org/10.1177\%2F0149206314527130.

Henriques, M. (2009). UK Databases, Global Linkage and Global Data Collection, Internal Dun \& Bradstreet $(D \& B)$ Report on the Representativeness and Reliability of the Global Reference Solutions (GRS) Database. Marlow, Buckinghamshire: D\&B UK Head Office.

Henseler, J., Ringle, C. M., \& Sarstedt, M. (2015). A new criterion for assessing discriminant validity in variance-based structural equation modelling. Journal of the Academy of Marketing Science, 43, 115-135. https://doi.org/10.1007/s1174.

Hobfoll, S. E. (2011). Conservation of resource caravans and engaged settings. Journal of Occupational and Organisational Psychology, 84, 116-122. https://doi.org/10.1111/j.2044-8325.2010.02016.x.

Hobfoll, S. E., Freedy, J., Lane, C., \& Geller, P. (1990). Conservation of social resources: Social support resource theory. Journal of Social and Personal Relationships, 7, 465-478. https://doi.org/10.1177/0265407590074004.

Howell, J. M., \& Higgins, C. A. (1990). Champions of technological innovation. Administrative Science Quarterly, 35, 317-341.

Hu, L. T., \& Bentler, P. M. (1999). Cutoff criteria for fit indexes in covariance structure analysis: Conventional criteria versus new alternatives. Structural equation modelling: A Multidisciplinary Journal, 6, 1-55.

Hughes, D. J., Lee, A., Tian, A. W., Newman, A., \& Legood, A. (2018). Leadership, creativity, and innovation: A critical review and practical recommendations. The Leadership Quarterly, 29, 549-569. https://doi.org/10.1016/j.leaqua.2018.03.

Husted, K., \& Michailova, S. (2002). Diagnosing and fighting knowledge-sharing hostility, Organisational Dynamics, 31, 60-73. https://doi: 10.1016/S0090-2616(02)00072-4.

Jackson, D. L., Gillaspy J. A., Jr., \& Purc-Stephenson, R. (2009). Reporting practices in confirmatory factor analysis: An overview and some recommendations. Psychological Methods, 14(1), 6-23. https://dx.doi.org/10.1037/a0014694.

Janssen, O., \& Van Yperen, N. W. (2004). Employees' goal orientations, the quality of leadermember exchange, and the outcomes of job performance and job satisfaction. Academy 
of Management Journal, 47, 368-384. http://dx.doi.org/10.2307/20159587.

Janssen, O., van de Vliert, E., \& West, M. (2004). The bright and dark sides of individual and group innovation: A special issue introduction. Journal of Organizational Behavior, 25, 129-145. https://doi.org/10.1002/job.242.

Jia, X., Chen, J., Mei, L. \& Wu, Q. (2018). How leadership matters in organisational innovation: a perspective of openness. Management Decision, 56, 6-25. https://doi.org/10.1108/md-04-2017-0415

Jiang, Y. \& Chen, C.C. (2018). Integrating knowledge activities for team innovation: effects of transformational leadership, Journal of Management, 44, 1819-1847. https://doi.org/10.1177\%2F0149206316628641 .

Jung, D.I., Chow, C. \& Wu, A. (2003). The role of transformational leadership in enhancing organisational innovation: Hypotheses and some preliminary findings. Leadership Quarterly, 14, 525-544. https://DOI: 10.1016/S1048-9843(03)00050-X.

Kark, R., \& Shamir, B. (2002). The duel effect of transformational leadership: Priming relational and collective selves and further effects on followers. In Avolio, B. Yammarino, F. (eds.). Transformational and Charismatic Leadership: The Road Ahead. Vol.2. pp.67-91. Stamford, CT: JAI Press.

Kleinbaum, D.G., Kupper, L.L. \& Muller, K.E. (1988). Variable reduction and factor analysis. Applied Regression Analysis and Other Multivariable Methods, 595-640. Boston, MA: PWS Kent Publishing Co.

Kline, R.B. (2005). Methodology in the Social Sciences. Principles and Practice of Structural Equation Modelling (2nd ed.). New York: The Guilford Press.

Kossek, E. E., \& Lautsch, B. A. (2018). Work-Life Flexibility for Whom? Occupational Status and Work-Life Inequality in Upper, Middle, and Lower Level Jobs. Academy of Management Annals, 12, 5-36. https://doi.org/10.5465/annals.2016.0059.

Kozlowski, S.W.J., Chao, G.T., Grand, J.A., Braun, M.T. \& Kuljanin, G. (2013). Advancing multilevel research design: Capturing the dynamics of emergence. Organisational Research Methods, 16, 581-616. https://doi.org/10.1177/1094428113493119.

Kreft, I. G.G., \& de Leeuw, J. (1998). Introducing Multilevel Modeling, Introducing Statistical Methods. London: Sage Publications.

Lee, J. (2001). The impact of knowledge sharing, organisational capability and partnership quality on IS outsourcing success, Information and Management, 38(5), 323-335. https://doi: 10.1016/S0378-7206(00)00074-4.

Li, G., Shang, Y., Liu, H. \& Xi, Y. (2014). Differentiated Transformational Leadership and 
Knowledge Sharing: A cross Level investigation, European Management Journal, 32 (4), 554-563. htpps://DOI: 10.1016/j.emj.2013.10.004.

Li, V., Mitchell, R. \& Boyle, B. (2016). The divergent effects of transformational leadership on individual and team innovation, Group \& Organisation Management, 41, 66-97. https://doi.org/10.1177/1059601115573792.

Lin, H. (2007). Knowledge sharing and firm innovation capability: An empirical study, International Journal of Manpower, 28, 315-332. https://doi: 10.1108/01437720710755272.

López-Cabrales, A., Pérez-Luño, A. \& Valle Cabrera, R. (2009). Knowledge as a mediator between HRM practices and innovative activity. Human Resource Management, 48, 785-503.https://doi: 10.1002hm.20295.

Lu, L., Leung, K. \& Koch, P.T. (2006). Managerial knowledge sharing: The role of individual, interpersonal, and organisational factors. Management and Organisation Review, 2, 14 41. https://doi.org/10.1111/j.1740-8784.2006.00029.x.

Mao, J. Y., Chiang, J. T. J., Chen, L., Wu, Y., \& Wang, J. (2019). Feeling safe? A conservation of resources perspective examining the interactive effect of leader competence and leader self-serving behaviour on team performance. Journal of Occupational and Organizational Psychology, 92, 52-73. https://doi.org/10.1111/joop.12233.

Marks, M.A., Mathieu, J.E., \& Zaccaro, S.J. (2001). A temporally based framework and taxonomy of team processes. Academy of Management Review, 26, 356-376. https://doi: $10.2307 / 259182$.

Miles, I. D., Belousova, V., \& Chichkanov, N. (2018). Knowledge intensive business services: ambiguities and continuities. Foresight, 20, 1-26. https://doi.org/10.1108/FS-10-20170058

OECD/Eurostat (2005). Oslo Manual: Guidelines for Collecting and Interpreting Innovation Data, 3rd Edition, The Measurement of Scientific and Technological Activities. Paris: OECD Publishing.

Pieterse, A. N., Van Knippenberg, D., \& van Ginkel, W. P. (2011). Diversity in goal orientation, team reflexivity, and team performance. Organizational Behavior and Human Decision Processes, 114(2), 153-164. https://dx.doi.org/10.1016/j.obhdp.2010.11.003.

Ployhart, R.E., \& Vandenberg, R.J. (2010). Longitudinal research: The theory, design and analysis of change, Journal of Management, 36(1), 94-120. https://oi: http://dx.doi.org/10.1177/0149206309352110.

Podsakoff, P. M., MacKenzie, S. B., \& Podsakoff, N. P. (2012). Sources of method bias in 
social science research and recommendations on how to control it. Annual Review of Psychology, 63, 539-569. https://doi.org/10.1146/annurev-psych-120710-100452.

Podsakoff, P.M. \& Organ, D.W. (1986). Self-reports in organisational research: Problems and prospects, Journal of Management, 12(4), 531-544. https://doi.org/10.1177/014920638601200408.

Preacher, K.J. \& Hayes, A.F. (2008). Asymptotic and resampling strategies for assessing and comparing indirect effects in multiple mediator models, Behavior Research Methods, 40(3), 879-891. https://doi.org/10.3758/BRM.40.3.879.

Rogerson, P.A. (2001). Statistical Methods for Geography. London: Sage.

Rosing, K., Frese, M. \& Bausch, A. (2011). Explaining the heterogeneity of the leadersinnovation relationship: Ambidextrous leadership, The Leadership Quarterly, 22, 956974. https://dx.doi.org/10.1016/j.leaqua.2011.07.014.

Salas-Vallina, A., Simone, C. \& Fernandez-Guerrero, R. (2018). The human side of leadership: Inspirational Leadership effects on follower characteristics and happiness at work (HAW). Journal of Business Research. https://doi.org/10.1016/j.jbusres.2018.10.044.

Sanders, K. \& Shipton, H. (2012). The relationship between transformational leadership and innovative behaviour in a healthcare context: a team learning versus a cohesion perspective. European Journal of International Management, 6, 83-100. https://10.1504/EJIM.2012.044759.

Shamir, B., Zakay, E., Breinin, E. \& Popper, M. (2000). Leadership and social identification in military units, Journal of Applied Social Psychology, 30(3), 612-640. https://doi: 10.1111/j.1559-1816.2000.tb02499.x.

Seung, Han,S., Seo,G., .H., Gaeun, S., Won Yoon, S. \& Yoon, D.Dong-Yeol, Y. (2016). Transformational leadership and knowledge sharing: Mediating roles of employee's empowerment, commitment, and citizenship behaviors. Journal of Workplace Learning, 28, 130-149. https://doi.org/10.1108/JWL-09-2015-0066

Stephens, J.P. \& Carmeli, A. (2017). Relational leadership and creativity: The effects of respectful engagement and caring on meaningfulness and creative work involvement. In S. Hemlin, S. \& M.D. Mumford (Eds), Handbook of Research on Leadership and Creativity. . (pp.273-296). Cheltenham: Edward Elgar Publishing.

Thevaraja, M., Rahman, A., \& Gabirial, M. (2019). Recent developments in data science: Comparing linear, ridge and lasso regressions techniques using wine data. In F. Hidoussi (Ed.), Proceedings of the International Conference on Digital Image \& Signal Processing (1st Ed., Vol. 1, pp. 1-6). UK: University of Oxford. 
Tippins, M.J. \& Sohi, R.S. (2003). IT competency and firm performance: Is organisational learning a missing link?. Strategic Management Journal, 24, 745-761. http://dx.doi.org/10.1002/smj.337.

Van de Schoot, R., Lugtig, P. \& Hox, J. (2012). A checklist for testing measurement Invariance. European Journal of Development Psychology, 9, 486-492. https://doi.org/10.1080/17405629.2012.686740.

Volberda, H. W., Van Den Bosch, F. A.J. \& Heij, C. V. (2013). Management Innovation: Management as Fertile Ground for Innovation. European Management Review, 10(1), 1-15. https://doi.org/10.1111/emre.12007.

Wang, X.H.F. \& Howell, J.M. (2012). A multilevel study of transformational leadership, identification, and follower outcomes. The Leadership Quarterly, 23, 775-790. https://doi:10.1016/j.leaqua.2012.02.001.

Wang, X.H.F., Kim, T.Y. \& Lee D.R. (2016). Cognitive diversity and team creativity: Effects of team intrinsic motivation and transformational leadership. Journal of Business Research, 69 (9), 3231-3239. https://DOI: 10.1016/j.jbusres.2016.02.026.

Wu, L., Zhu, R., \& Yang. Y. (2010). I warn you because I like you: Voice Behavior, employee identifications and transformational leadership. The Leadership Quarterly, 21, 189-202. https://DOI:10.1016/j.leaqua.2009.10.014.

Zhang, X.A., Li, N., Ullrich, J. \& van Dick, R. (2015). Getting everyone on board: The effect of differentiated transformational leadership by CEOs on top management team effectiveness and leader-rated firm performance. Journal of Management, 41, 18981933. https://dx.doi.org/10.1177/0149206312471387.

Zohar, D. \& Tenne-Gazit, O. (2008). Transformational leadership and group interaction as climate antecedents: a social network analysis. Journal of Applied Psychology, 93, 744757. https://doi: 10.1037/0021-9010.93.4.744.

Zuraik, A. \& Kelly, L. (2019). The role of CEO transformational leadership and innovation climate in exploration and exploitation. European Journal of Innovation Management 22 (1), 84-104. https://doi.org/10.1108/EJIM-10-2017-0142. 
Figure 1: Research Model

\begin{tabular}{|c|c|c|c|c|c|c|}
\hline $\begin{array}{l}\text { Unit-Level } \\
\text { Transformational } \\
\text { Leadership } \\
\text { (TFL) }\end{array}$ & $\stackrel{\mathrm{H} 2}{\longrightarrow}$ & $\begin{array}{c}\text { Unit } \\
\text { Knowledge } \\
\text { Sharing } \\
\text { Climate }\end{array}$ & $\stackrel{\mathrm{H} 3}{\stackrel{\mathrm{H} 2}{\mathrm{H}}} \underset{ }{\longrightarrow}$ & $\begin{array}{l}\text { Internal to } \\
\text { Unit } \\
\text { Knowledge } \\
\text { Sharing }\end{array}$ & $\stackrel{\mathrm{H} 3}{\longrightarrow} \underset{\mathrm{H} 4}{\longrightarrow}$ & $\begin{array}{c}\text { Unit } \\
\text { Innovation } \\
\text { Performance } \\
\text { (IPerf) }\end{array}$ \\
\hline & & & H1 & & & \\
\hline
\end{tabular}


Table 1: Means, Standard Deviations and Correlations of Study Variables

\begin{tabular}{|c|c|c|c|c|c|c|c|c|c|c|c|}
\hline Construct & Mean & SD & 1 & 2 & 3 & 4 & 5 & 6 & 7 & 8 & 9 \\
\hline $\begin{array}{l}\text { V1 } \ln (\text { Size of Unit) }(t \\
=1)\end{array}$ & 83.8 & 127.78 & & & & & & & & & \\
\hline $\begin{array}{l}\text { V2 } \ln \text { (Age of Unit) (t } \\
=1)\end{array}$ & 17.8 & 30.67 & 0.09 & & & & & & & & \\
\hline $\begin{array}{l}\text { V3 Single-site unit }(\mathrm{t} \\
=1)\end{array}$ & 0.61 & 0.46 & -0.06 & $\begin{array}{l}-0.13 \\
\end{array}$ & & & & & & & \\
\hline $\begin{array}{l}\text { V4 Prior unit } \\
\text { innovation } \\
\text { performance }(t=1)\end{array}$ & 3.89 & 1.47 & 0.07 & $\begin{array}{l}-0.06 \\
\end{array}$ & -0.09 & & & & & & \\
\hline $\begin{array}{l}\text { V5 } \ln \text { (prior unit- } \\
\text { financial performance } \\
\text { (profit per } \\
\text { employee)), }(t=1))\end{array}$ & 3.37 & 2.19 & 0.12 & $\begin{array}{l}-0.10 \\
\end{array}$ & -0.08 & $0.25 * *$ & & & & & \\
\hline $\begin{array}{l}\text { V6 Median employee } \\
\text { education }(t=1)\end{array}$ & 2.54 & 1.15 & 0.13 & 0.11 & -0.10 & $0.33 * * *$ & $0.14 *$ & & & & \\
\hline $\begin{array}{l}\text { V7 Unit-Level } \\
\text { Transformational } \\
\text { Leadership }(T F L)(t= \\
\text { 1) }\end{array}$ & 3.11 & 1.07 & 0.05 & 0.06 & 0.08 & $0.21^{* *}$ & $0.17^{*}$ & 0.10 & & & \\
\hline $\begin{array}{l}\text { V8 Unit Knowledge- } \\
\text { sharing Climate } \\
(\text { KSC) }(\mathrm{t}=1)\end{array}$ & 4.03 & 0.78 & 0.07 & $\begin{array}{l}-0.04 \\
\end{array}$ & 0.09 & $0.25^{* *}$ & 0.08 & $0.13 *$ & $0.41^{* * *}$ & & \\
\hline $\begin{array}{l}\text { V9 Internal to unit } \\
\text { Knowledge Sharing } \\
\text { (IKS) }(\mathrm{t}=1)\end{array}$ & 3.98 & 0.71 & 0.03 & -0.05 & 0.10 & $0.15^{*}$ & 0.09 & $0.14 *$ & $0.23 * *$ & $0.68^{* * *}$ & \\
\hline $\begin{array}{l}\text { V10 Unit Innovation } \\
\text { performance (IPerf) } \\
(\mathrm{t}=2)\end{array}$ & 4.16 & 1.97 & 0.09 & -0.07 & -0.05 & $0.57^{* * *}$ & $0.39^{* * *}$ & $0.16^{*}$ & $0.62 * * *$ & $0.35 * * *$ & $0.22^{* *}$ \\
\hline
\end{tabular}

Note 1: $n=124$

Note 2: ${ }^{*} p<0.05 ; * * p<0.01$ and $* * * p<0.001$ (two-tailed t-tests) 
Table 2: Multiple Regression Results

\begin{tabular}{|c|c|c|c|c|c|c|c|c|c|c|c|}
\hline Variable & $\begin{array}{c}\text { Unit } \\
\text { Innovation } \\
\text { Performance } \\
(t=2) \\
\text { Base Model } \\
\quad(1)\end{array}$ & $\begin{array}{c}\text { Unit } \\
\text { Innovation } \\
\text { Performance } \\
(t=2) \\
\text { (2) }\end{array}$ & $\begin{array}{l}\text { Unit KSC } \\
\qquad(t=1)\end{array}$ & $\begin{array}{l}\text { Unit KSC } \\
\qquad(t=1)\end{array}$ & $\begin{array}{l}\text { Unit KSC } \\
\qquad(\mathrm{t}=1)\end{array}$ & $\begin{array}{c}\text { Unit } \\
\text { Innovation } \\
\text { Performance } \\
(t=2) \\
(6)\end{array}$ & $\begin{array}{c}\text { Unit } \\
\text { Innovation } \\
\text { Performance } \\
(t=2) \\
(7)\end{array}$ & $\begin{array}{c}\text { Unit } \\
\text { Innovation } \\
\text { Performance } \\
(\mathrm{t}=2) \\
(8)\end{array}$ & $\begin{array}{c}\text { Unit } \\
\text { Innovation } \\
\text { Performance } \\
(t=2) \\
(9)\end{array}$ & $\begin{array}{c}\text { Unit } \\
\text { Innovation } \\
\text { Performance } \\
(t=2) \\
(10)\end{array}$ & $\begin{array}{c}\text { Unit } \\
\text { Innovation } \\
\text { Performance } \\
(t=2) \\
(11)\end{array}$ \\
\hline Intercept & $\begin{array}{c}2.227^{* *} \\
(1.012) \\
\end{array}$ & $\begin{array}{c}1.998^{* *} \\
(0.917)\end{array}$ & $\begin{array}{c}2.597 * * * \\
(0.812)\end{array}$ & $\begin{array}{l}1.234^{* *} \\
(0.514)\end{array}$ & $\begin{array}{l}1.234 * * \\
(0.514)\end{array}$ & $\begin{array}{l}2.232 * * \\
(0.930)\end{array}$ & $\begin{array}{c}2.234^{* *} \\
(0.930)\end{array}$ & $\begin{array}{l}1.993^{* *} \\
(0.916)\end{array}$ & $\begin{array}{c}1.999 * * \\
(0.917)\end{array}$ & $\begin{array}{c}1.997 * * \\
(0.917)\end{array}$ & $\begin{array}{l}1.987 * \\
(0.912) \\
\end{array}$ \\
\hline $\begin{array}{l}\mathrm{Ln} \text { (size of unit) (t= } \\
\text { 1) }\end{array}$ & $\begin{array}{c}0.088 \\
(0.159)\end{array}$ & $\begin{array}{c}0.085 \\
(0.064)\end{array}$ & $\begin{array}{c}0.105 \\
(0.161)\end{array}$ & $\begin{array}{l}-0.102 \\
(0.053)\end{array}$ & $\begin{array}{l}-0.102 \\
(0.053)\end{array}$ & $\begin{array}{c}0.083 \\
(0.062)\end{array}$ & $\begin{array}{c}0.084 \\
(0.063)\end{array}$ & $\begin{array}{c}0.084 \\
(0.062)\end{array}$ & $\begin{array}{c}0.085 \\
(0.063)\end{array}$ & $\begin{array}{c}0.083 \\
(0.063)\end{array}$ & $\begin{array}{c}0.082 \\
(0.062)\end{array}$ \\
\hline $\begin{array}{l}\mathrm{Ln} \text { (age of unit) }(\mathrm{t}= \\
\text { 1) }\end{array}$ & $\begin{array}{c}0.108 \\
(0.078)\end{array}$ & $\begin{array}{c}0.103 \\
(0.076)\end{array}$ & $\begin{array}{c}0.097 \\
(0.188)\end{array}$ & $\begin{array}{c}0.005 \\
(0.188)\end{array}$ & $\begin{array}{c}0.005 \\
(0.188)\end{array}$ & $\begin{array}{c}0.103 \\
(0.074)\end{array}$ & $\begin{array}{c}0.102 \\
(0.075)\end{array}$ & $\begin{array}{c}0.102 \\
(0.077)\end{array}$ & $\begin{array}{c}0.103 \\
(0.076)\end{array}$ & $\begin{array}{c}0.103 \\
(0.075)\end{array}$ & $\begin{array}{c}0.103 \\
(0.075)\end{array}$ \\
\hline $\begin{array}{l}\text { Single-site unit }(t= \\
\text { 1) }\end{array}$ & $\begin{array}{l}-0.090 \\
(0.142)\end{array}$ & $\begin{array}{l}-0.089 \\
(0.139)\end{array}$ & $\begin{array}{c}0.108 \\
(0.065)\end{array}$ & $\begin{array}{l}-0.089 \\
(0.073)\end{array}$ & $\begin{array}{l}-0.089 \\
(0.073)\end{array}$ & $\begin{array}{l}-0.087 \\
(0.1376\end{array}$ & $\begin{array}{l}-0.088 \\
(0.137)\end{array}$ & $\begin{array}{l}-0.088 \\
(0.137)\end{array}$ & $\begin{array}{l}-0.087 \\
(0.136)\end{array}$ & $\begin{array}{l}-0.089 \\
(0.136)\end{array}$ & $\begin{array}{l}-0.087 \\
(0.137)\end{array}$ \\
\hline $\begin{array}{l}\text { Prior unit } \\
\text { innovation } \\
\text { performance }(t=1)\end{array}$ & $\begin{array}{l}0.127^{* *} \\
(0.057)\end{array}$ & $\begin{array}{l}0.118^{*} \\
(0.059)\end{array}$ & $\begin{array}{l}0.139 * * \\
(0.063)\end{array}$ & $\begin{array}{l}0.148^{* *} \\
(0.061)\end{array}$ & $\begin{array}{l}0.148^{* *} \\
(0.061)\end{array}$ & $\begin{array}{l}0.120^{*} \\
(0.060)\end{array}$ & $\begin{array}{l}0.120^{*} \\
(0.060)\end{array}$ & $\begin{array}{l}0.120^{*} \\
(0.061)\end{array}$ & $\begin{array}{l}0.119^{*} \\
(0.059)\end{array}$ & $\begin{array}{l}0.118^{*} \\
(0.059)\end{array}$ & $\begin{array}{l}0.122^{*} \\
(0.059)\end{array}$ \\
\hline $\begin{array}{l}\text { Ln (prior financial } \\
\text { performance) }(\mathrm{t}= \\
\text { 1)) }\end{array}$ & $\begin{array}{l}0.106^{*} \\
(0.054)\end{array}$ & $\begin{array}{l}0.108 * \\
(0.053)\end{array}$ & $\begin{array}{c}0.104 \\
(0.063)\end{array}$ & $\begin{array}{c}0.097 \\
(0.080)\end{array}$ & $\begin{array}{c}0.097 \\
(0.080)\end{array}$ & $\begin{array}{l}0.105^{*} \\
(0.052)\end{array}$ & $\begin{array}{l}0.106^{*} \\
(0.052)\end{array}$ & $\begin{array}{l}0.109 * \\
(0.054)\end{array}$ & $\begin{array}{l}0.109^{*} \\
(0.053)\end{array}$ & $\begin{array}{l}0.107^{*} \\
(0.053)\end{array}$ & $\begin{array}{l}0.108^{*} \\
(0.052)\end{array}$ \\
\hline $\begin{array}{l}\text { Median employee } \\
\text { education }(t=1)\end{array}$ & $\begin{array}{l}0.167 * * \\
(0.070)\end{array}$ & $\begin{array}{c}0.159^{* * *} \\
(0.068)\end{array}$ & $\begin{array}{c}0.162^{* *} \\
(0.069)\end{array}$ & $\begin{array}{c}0.156^{* *} \\
(0.068)\end{array}$ & $\begin{array}{c}0.156^{* *} \\
(0.068)\end{array}$ & $\begin{array}{l}0.158^{* *} \\
(0.068)\end{array}$ & $\begin{array}{l}0.157^{* *} \\
(0.068)\end{array}$ & $\begin{array}{c}0.158^{* *} \\
(0.069)\end{array}$ & $\begin{array}{c}0.159^{* *} \\
(0.067)\end{array}$ & $\begin{array}{c}0.158^{* *} \\
(0.067)\end{array}$ & $\begin{array}{c}0.156^{* *} \\
(0.067)\end{array}$ \\
\hline $\begin{array}{l}\text { Unit Level } \\
\text { Transformational } \\
\text { Leadership (TFL) (t } \\
=1 \text { ) }\end{array}$ & - & $\begin{array}{c}0.372 * * * \\
(0.098)\end{array}$ & $\begin{array}{c}0.321^{* * *} \\
(0.106)\end{array}$ & $\begin{array}{c}0.478^{* * *} \\
(0.137)\end{array}$ & $\begin{array}{c}0.289^{* *} \\
(0.131)\end{array}$ & - & - & - & $\begin{array}{l}0.216^{*} \\
(0.120)\end{array}$ & $\begin{array}{c}0.253^{* *} \\
(0.115)\end{array}$ & $\begin{array}{l}0.219^{*} \\
(0.114)\end{array}$ \\
\hline $\begin{array}{l}\text { Unit Knowledge- } \\
\text { sharing Climate } \\
(\mathrm{KSC}) \\
(\mathrm{t}=1)\end{array}$ & - & - & - & & $\begin{array}{c}0.511^{* * *} \\
(0.159)\end{array}$ & $\begin{array}{l}0.273 * * \\
(0.121)\end{array}$ & - & $\begin{array}{l}0.197 * \\
(0.110)\end{array}$ & $\begin{array}{l}0.196^{*} \\
(0.109)\end{array}$ & - & $\begin{array}{l}0.195^{*} \\
(0.109)\end{array}$ \\
\hline $\begin{array}{l}\text { Internal to unit } \\
\text { Knowledge Sharing } \\
\text { (IKS) }(\mathrm{t}=1)\end{array}$ & - & - & - & - & - & - & $\begin{array}{c}0.471 * * * \\
(0.135)\end{array}$ & $\begin{array}{l}0.469 * * * \\
(0.135)\end{array}$ & - & $\begin{array}{l}0.467 * * * \\
(0.133)\end{array}$ & $\begin{array}{c}0.465 * * * \\
(0.134)\end{array}$ \\
\hline $\begin{array}{l}\text { Adjusted } \mathrm{R}^{2} \\
\text { (innovation models } \\
\text { only) }\end{array}$ & 0.287 & 0.402 & - & - & - & 0.501 & 0.634 & 0.673 & 0.682 & 0.784 & 0.896 \\
\hline Change $\mathrm{R}^{2}$ & - & 0.115 & - & - & - & 0.099 & 0.133 & 0.039 & 0.09 & 0.102 & 0.112 \\
\hline F-stat & $31.263 * * *$ & $23.53 * * *$ & - & - & - & $14.361 * * *$ & $12.345^{* * *}$ & $10.456^{* * *}$ & $7.786 * *$ & $5.116^{* *}$ & $4.976^{* *}$ \\
\hline
\end{tabular}

Note 1: $\mathrm{n}=124$

Note 2 : ${ }^{*} p<0.05 ;{ }^{* *} p<0.01$; and ${ }^{* * *} p<0.001$ (two-tailed tests) 
Table 3: Mediation of the Effect of Unit Level TFL on Unit Innovation Performance through Knowledge Sharing Climate and Internal to Unit Knowledge Sharing: Indirect Effects

\begin{tabular}{|c|c|c|c|c|c|c|c|}
\hline & $\begin{array}{c}\text { Point Estimate } \\
\text { (1) }\end{array}$ & $\begin{array}{c}\text { Product of } \\
\text { Coefficients: } \\
\text { (2) }\end{array}$ & 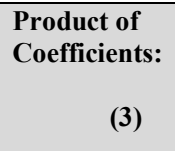 & $\begin{array}{l}\text { Bootstrapped BC } \\
95 \% \text { CIs: } \\
\text { (4) }\end{array}$ & $\begin{array}{l}\text { Bootstrapped BC } \\
\text { 95\% CIs: } \\
\text { (5) }\end{array}$ & $\begin{array}{l}\text { Bootstrapped BCa } \\
\text { 95\% CIs: } \\
\text { (6) }\end{array}$ & $\begin{array}{l}\text { Bootstrapped BCa } \\
\text { 95\% CIs: } \\
\text { (7) }\end{array}$ \\
\hline Mediator & & SE & $\mathbf{Z}$ & Lower & Upper & Lower & Upper \\
\hline KSC & 0.0685 & 0.0248 & 2.762 & 0.0348 & 0.1397 & 0.0371 & 0.1405 \\
\hline IKS & 0.0712 & 0.0239 & 2.979 & 0.0396 & 0.1492 & 0.0416 & 0.1502 \\
\hline TOTAL & 0.1397 & 0.0443 & 3.153 & 0.0744 & 0.2889 & 0.0787 & 0.2907 \\
\hline
\end{tabular}

Note: $\mathrm{BC}=$ bias corrected; $\mathrm{BCa}=$ bias corrected and accelerated; 5,000 bootstrap samples (see Preacher and Hayes, 2008). 